\title{
Plant-hummingbird interactions and temporal nectar availability in a restinga from Brazil
}

\section{LORENA C.N. FONSECA ${ }^{1,5}$, JEFERSON VIZENTIN-BUGONI ${ }^{2,6}$, ANDRÉ R. RECH ${ }^{3}$ and MARIA ALICE S. ALVES ${ }^{4}$}

\author{
${ }^{1}$ Programa de Pós-Graduação em Ecologia, Universidade Federal do Rio de Janeiro/ \\ UFRJ, CCS, IB, Caixa Postal 68020, 21941-590 Rio de Janeiro, RJ, Brasil \\ ${ }^{2}$ Programa de Pós-Graduação em Ecologia, Instituto de Biologia, Universidade Estadual de Campinas/ \\ UNICAMP, Rua Monteiro Lobato, 970, Barão Geraldo, 13083-970 Campinas, SP, Brasil \\ ${ }^{3}$ Instituto de Biologia, Universidade Federal de Uberlândia/UFU, Av. Pará, 1720, \\ Campus Umuarama, 38405-320 Uberlândia, MG, Brasil \\ ${ }^{4}$ Departamento de Ecologia, Instituto de Biologia Roberto Alcantara Gomes, Universidade do Estado do Rio \\ de Janeiro/UERJ, Rua São Francisco Xavier, 524, Maracanã, 20550-011 Rio de Janeiro, RJ, Brasil \\ ${ }^{5}$ Companhia Ambiental do Estado de São Paulo/CETESB, Av. Professor Frederico \\ Hermann Jr, 345, Pinheiros, 05459-900 São Paulo, SP, Brasil \\ ${ }^{6}$ Center for Macroecology, Evolution and Climate, Natural History Museum of Denmark, \\ University of Copenhagen, Universitetsparken 15, DK-2100 Copenhagen Ø, Denmark
}

Manuscript received on July 10, 2014; accepted for publication on April 27, 2015

\begin{abstract}
Hummingbirds are the most important and specialized group of pollinating birds in the Neotropics and their interactions with plants are key components to many communities. In the present study we identified the assemblage of plants visited by hummingbirds and investigated the temporal availability of floral resources in an area of restinga, sandy plain coastal vegetation associated with the Atlantic forest, in Southeastern Brazil. We recorded flower and nectar features, flowering phenology and interactions between plants and hummingbirds and estimated the amount of calories produced per hectare from June 2005 to August 2006. Ten plant species were visited by two hummingbirds, Amazilia fimbriata and Eupetomena macroura. Resource availability was highly variable among plant species and over time. Nectar volume and concentration per flower were similar to other Neotropical hummingbird-visited plant assemblages. The estimated nectar resource availability between months varied from 0.85 to $5.97 \mathrm{Kcal}$ per hectare/day, demanding an area between one and 6.8 ha to support a single hummingbird. Our study reports an unusual tropical setting where almost all interactions between hummingbirds and plants were performed by a single hummingbird species, A. fimbriata. Hence, the variable nectar availability is probably influencing hummingbird movements, its foraging area, and consequently plant pollination.
\end{abstract}

Key words: Amazilia fimbriata, Atlantic rainforest, floral resources, ornitophily, pollination, restinga.

\section{INTRODUCTION}

Hummingbirds are numerically and ecologically dominant in bird-flower interactions in the New World, where they play a crucial role pollinating

Correspondence to: Maria Alice S. Alves

E-mail: masaalves19@gmail.com many plant species in different ecosystems (Stiles 1981, Mendonça and Anjos 2003). These birds also feed on small arthropods but they obtain most of their energy requirement from nectar, being highly specialized on this diet (Stiles 1978, Cronk and Ojeda 2008). While feeding, hummingbirds may pollinate flowers, establishing therefore a 
mutualistic relationship with many of the plants they visit (Bawa 1990, Buzato et al. 2000, Abrahamczyc and Kessler 2015, but see Maruyama et al. 2013). However, nectar production is costly for plants and its availability in nature is highly complex giving rise to a wide array of nectar production strategies (Pyke 1991, McDade and Weeks 2004). For instance, at the community level, plant species can produce nectar with distinct sugar compositions (Galetto and Bernardello 2003) or rates (MacDade and Weeks 2004). Furthermore, hummingbirdflowers vary greatly on flowering seazonality and length (e.g. Buzato et al. 2000, Maruyama et al. 2014, Vizentin-Bugoni et al. 2014). The resulting spatial and temporal dynamics of food resources may have direct effects on the hummingbird assemblages (Cotton 2000) and, consequently influence plant pollination (Stiles 1978, 1985).

According to patterns of nectar availability, hummingbirds present a continuum of behavioral strategies, from trapliners (commonly species from the Hermits clade) that usually visit dispersed flowers that produces higher amount of reward per flower, to territorial species (usually nonhermits species) which generally feed on grouped flowers producing a lower volume of more diluted nectar (Stiles 1975, Feinsinger and Colwell 1978). Therefore both, behavioral strategy and nectar availability, play a central role in determining the foraging area of a hummingbird (Feinsinger and Colwell 1978). Moreover, entire plant assemblage studies in seasonal areas of Central South America have reported most hummingbirds as being generalists, feeding on a wide array of ornithophilous and non-ornithophilous flowers (Oliveira and Gibbs 2000, Araújo and Sazima 2003, Maruyama et al. 2013 and references therein).

Some simpler tropical ecosystems, like the Brazilian restingas which present lower diversity, productivity and structural complexity in comparison to Atlantic Forest, for instance (Scarano 2002), offer the opportunity to better understand the ecological issues concerning the nectar dynamics and the structure of plant-pollinator interactions in this region. Restingas are geologically recent environments (less than 120,000 years before present) where shrubland vegetation grows on nearshore, sandy soils (Souza et al. 2008). The soil of restinga tends to require plant adaptations to support drought, salinity and/or low nutrient availability (Scarano et al. 2001). Given the harsh conditions of restingas, plant colonization is hampered and often facilitation by nurse plants is crucial for the establishment of other plant species (Scarano 2002, Sampaio et al. 2005). In the Southeastern Brazilian restingas, one of the most important nurse plants is the mainly hummingbird-pollinated bromeliad Aechmea nudicaulis (Sampaio et al. 2005, Schmid et al. 2011). Therefore, the maintenance of these nurse plants, and consequently its ecological role, rely to some extent on the hummingbirds. Despite the importance of these interactions for the ecosystem functioning, to our best knowledge there are no previous studies on plant-hummingbirds interactions at community level in restingas.

In this context, here we described the structure of a plant-hummingbird assemblage in a restinga area and estimated the energy production by the plants. In order to characterize the relationship between hummingbirds and their resources, we also described the floral morphology, phenology and nectar production for the hummingbird-visited plants in the assemblage. Based on our findings, we discuss the possible implications of nectar dynamics on hummingbird foraging area and plant reproduction.

\section{MATERIALS AND METHODS}

\section{STUDY AREA}

The present study was carried out in the "Restinga de Jurubatiba" National Park (RJNP, 22 16 '41'S; $\left.41^{\circ} 39^{\prime} 41^{\prime \prime} \mathrm{W}\right)$, located on the coast of the state of Rio de Janeiro, Brazil (Fig. 1). The RJNP is the only national protected area specifically designed to preserve restinga ecosystems in Brazil. The 
restinga is characterized by geologically recent sandy coastal plain adjacent to the core Atlantic rainforest (Souza et al. 2008). The vegetation of the study area is dominated by patches of Clusia hilariana called "non-flooded open shrubland" ("restinga arbustiva aberta não inundável", in Portuguese) (Magnano et al. 2011), with the forested physiognomy nearby (Araujo et al. 1998). The rainfall is seasonally distributed varying from $40 \mathrm{~mm}$ per month during winter (from June to September) to $190 \mathrm{~mm}$ per month during summer (from December to February, Henriques et al. 1986). Mean annual temperature varies around 22 ${ }^{\circ} \mathrm{C}$ (Araujo et al. 1998).

\section{SAMPLING METHOD}

Data collection was carried out from June 2005 to August 2006. We established five consecutive quadrants of $200 \times 40 \mathrm{~m}\left(8,000 \mathrm{~m}^{2}\right)$ covering a total area of $40,000 \mathrm{~m}^{2}$. Each month, from August 2005 to August 2006, one of our researchers (L.C.N.
Fonseca) monitored the transects (five transects of $200 \mathrm{~m}$ each) twice a day. Monitoring was carried out by walking slowly across each quadrant starting between 6:00-8:00 and 16:00-18:00 and expending around $3 \mathrm{~h}$ per turn/month observing, summing $78 \mathrm{~h}$ of observations. Along the transects we identified and quantified hummingbirds, flower visitation and agonistic interactions. Legitimate visits by insects were also quantified. According to our previous observations, our sampling period coincides with higher activity of hummingbirds. Flower morphology and nectar measurements were taken from June 2005 to May 2006 along the same quadrants. We randomly set 30 plots $(20 \times 20 \mathrm{~m})$ totalling $12,000 \mathrm{~m}^{2}$ inside the five bigger 200 x $40 \mathrm{~m}$ quadrants. Inside these plots, we described flowering phenology and number of opened flowers once a month and measured nectar features from the hummingbird-visited plants. Although occurring only nearby and not inside the plots, we also included the Quesnelia quesneliana in the sampling in order to present a more complete

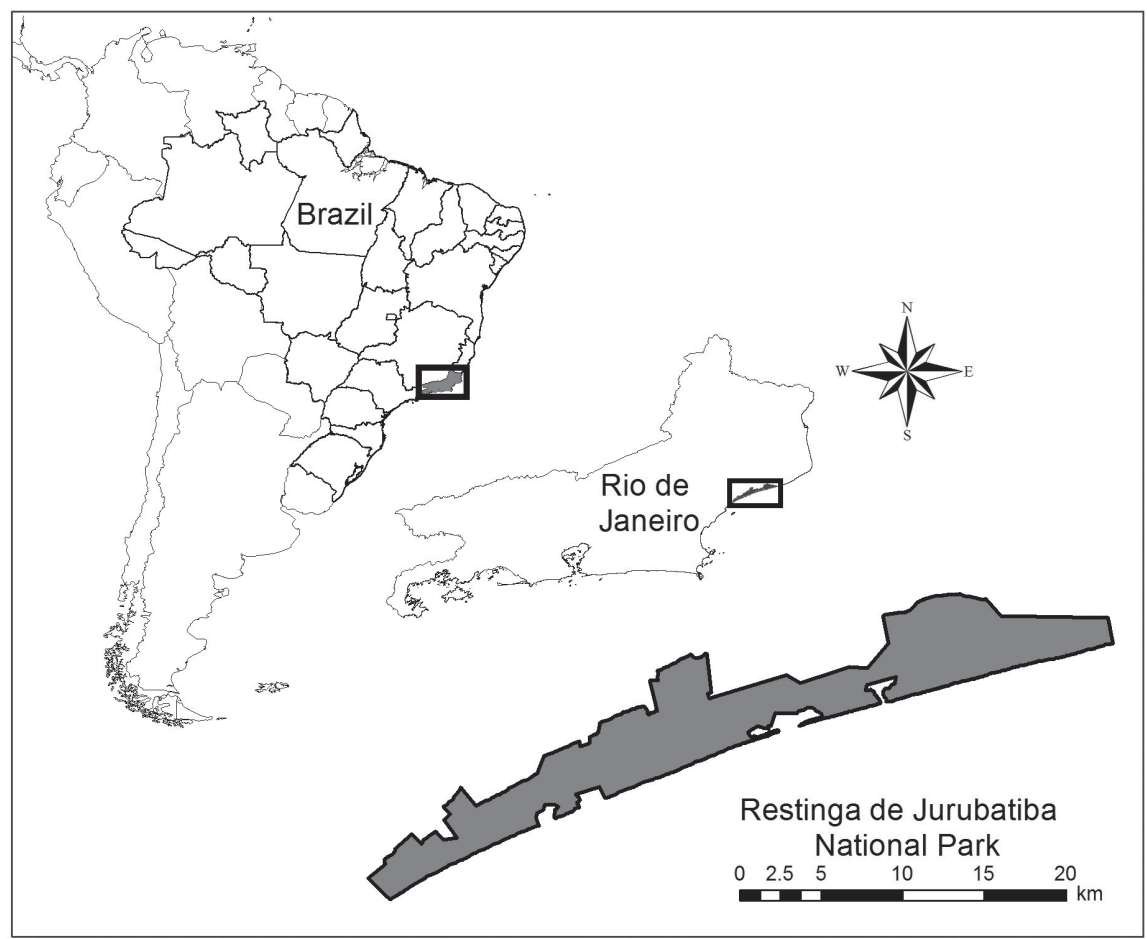

Figure 1 - Restinga de Jurubatiba National Park, located on the coast of the state of Rio de Janeiro, Southeastern Brazil. 
overview of the hummingbird-pollinated plants in the open Clusia scrubland. Hence, this species was also included because the genus is known to be an important source of nectar to hummingbirds (Buzato et al. 2000). Plant names cited here follows indications of the Tropicos database (http://www. tropicos.org) and The Plant List (http://www. theplantlist.org) for the classification system.

\section{FLOWER MORPHOLOGY AND NECTAR FEATURES}

We classified flower morphology as "open" or "tubular". For the tubular flowers visited by hummingbirds we measured the length of corolla tube (from the base to the opening) using a digital calliper ( $0.1 \mathrm{~mm}$ precision). We quantified nectar volume and sugar concentration in all hummingbird-visited plants inside the quadrants, from flower buds bagged one day before anthesis, using micro-syringes and a handheld refractometer. Although outside of the sampling quadrants (but very close) we also measured the nectar features of Quesnelia quesneliana, since it is a tubular ornithophilous species with no description of nectar features in literature. In order to compare standardized measurements of nectar production over the year, inside the quadrants, we measured the accumulated volume of each flower before senescence (between 14:00 and17:00). We used a Pearson correlation to test the relation between corolla length and nectar volume of legitimately visited species.

\section{ENERGY PRODUCTION BY THE PLANT ASSEMBLAGE}

Nectar volume and sugar concentration were used to calculate the daily amount of energy available per flower (1 mg = 4 calories sensu Dafni 1992, Galetto and Bernardello 2003). Energy (calories) available per flower (Araujo et al. 2011) was multiplied by the total amount of counted flowers produced by each individual of each species and summed up to estimate the total amount of calories produced in the area per day. This estimate is conservative because nectar is not used just by hummingbirds, but sometimes shared with insect visitors. We are also aware of the possible overestimation (8$11 \%$ ) due to refractive substances present in the nectar that may not be converted into energy by the hummingbirds, but we included this possible bias as a component of the conservative estimate (Inouye et al. 1980). Moreover, part of the refractive substances present in nectar, such as amino acids and lipids, also have caloric values reducing the possible bias (Galetto and Bernardello 2003) and we could not measure them. We used 6-10 Kcal as a daily energetic demand parameter for an individual hummingbird (Carpenter 1983).

\section{RESULTS}

Amazilia fimbriata and Eupetomena macroura visited ten plant species inside the sampled quadrants at the Jurubatiba restinga. Amazilia fimbriata visited all plants, acting as potential pollen vector in nine of them, but did not touch anthers and stigmas in Passiflora alliacea (Passifloraceae) flowers (Fig. 2). Eupetomena macroura visited only Mandevilla guanabarica (Apocynaceae) (Table I). Additionally, we recorded Mimus gilvus (Mimidae) once inside the quadrants, legitimately visiting Schwartzia brasiliensis (Marcgraviaceae). Except Phaethornis idaliae, recorded visiting three bromeliad species nearby the forest edge and therefore outside the plot (Table I), there was no record of other hummingbird species visiting flowers within or in the vicinity of the sampled area.

In general, visits by insects were infrequent, but some legitimate visits by bees were recorded in the following plant species: G. brasiliensis (one visit), M. guanabarica (two visits by Euglossa sp.), P. alliacea (often visited by Xylocopa sp.); and by butterflies: A. nudicaulis (two visits), $M$. guanabarica (five visits). Bromeliaceae was the species-richest family with six species (Table I). Most hummingbird-visited plants showed flowers with tubular robust corollas and variation from red 


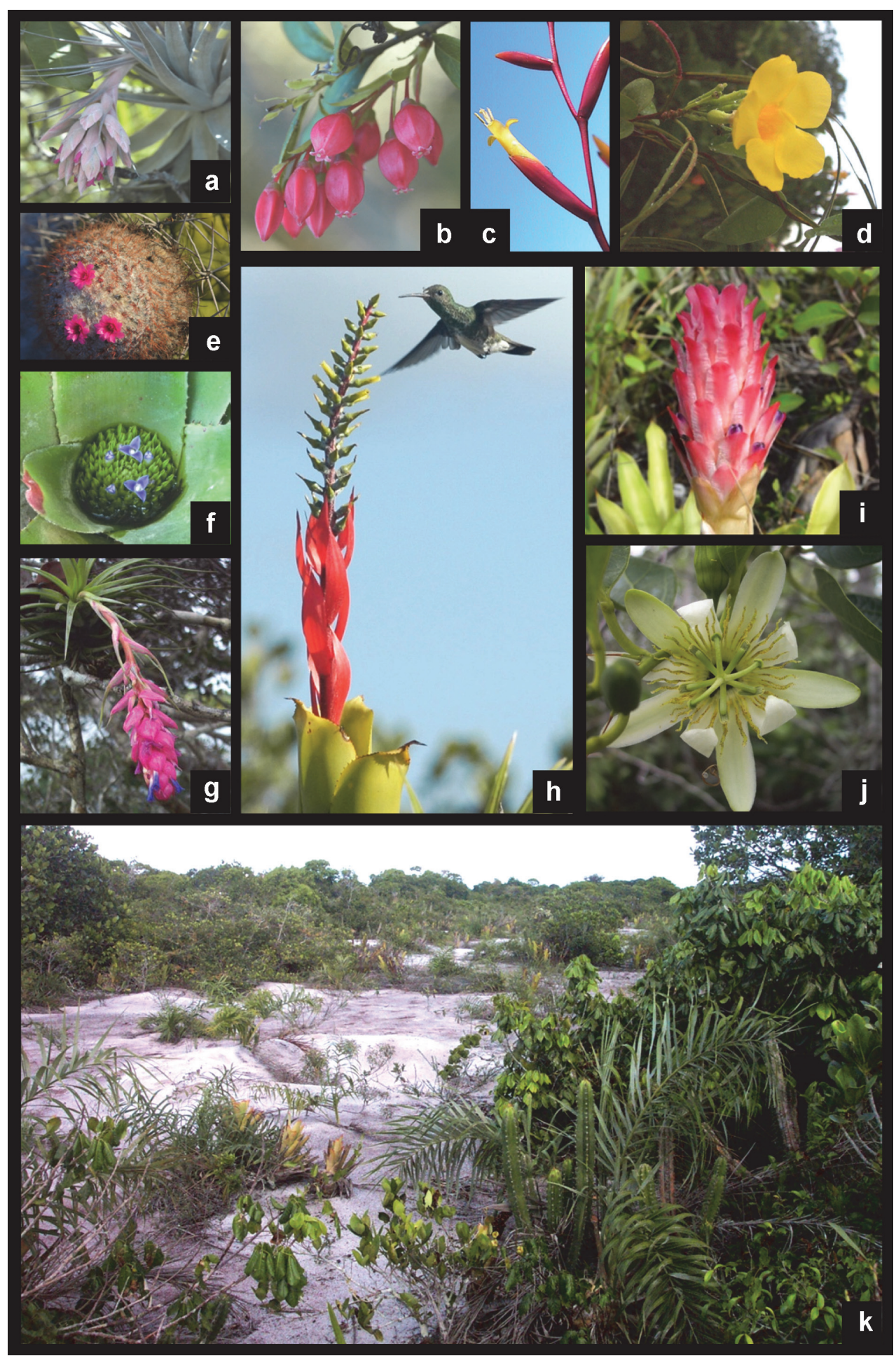

Figure 2 - Plants visited by the hummingbirds inside the studied quadrants at the Restinga de Jurubatiba National Park, Rio de Janeiro, Brazil. a - Tillandsia gardneri, b - Gaylussacia brasiliensis, c - Vriesea neoglutinosa, d - Mandevilla guanabarica, e - Melocactus violaceus, f - Neoregelia cruenta, $\mathbf{g}$ - Tillandsia stricta, $\mathbf{h}$ - Aechmea nudicaulis with the hummingbird Amazilia fimbriata, $\mathbf{i}$ Quesnelia quesneliana, $\mathbf{j}$ - Passiflora alliacea, $\mathbf{k}$ - Overview of the studied area. Claudio de Fraga is the author of photos a and $\mathbf{i}$, Dinkum of photo $\mathbf{f}$ (via Creative Commons). 
TABLE I

Ten plant species visited legitimately and illegitimately (*) by hummingbirds in Restinga de Jurubatiba National Park, Southeastern Brazil and their mean corolla length $(\mathrm{mm})$, flower shape, pollination syndromes and number of visits by each hummingbird species. All visits of Phaethonis idaliae were opportunistic, observed nearby the forest, outside the sampling quadrant.

\begin{tabular}{|c|c|c|c|}
\hline Family/Species & Corolla length mean \pm sd (n) & Pollination syndrome & Hummingbird visitor (N. visits) \\
\hline \multicolumn{4}{|l|}{ Apocynaceae } \\
\hline $\begin{array}{l}\text { Mandevilla guanabarica Casar. Ex } \\
\text { M.F.Sales, Kin-Gouv. and A.O.Simões }\end{array}$ & $34.7 \pm 2.20(44)$ & Melittophily & $\begin{array}{l}\text { A. fimbriata }(18) \\
\text { E. macroura }(1)\end{array}$ \\
\hline \multicolumn{4}{|l|}{ Bromeliaceae } \\
\hline & & & A. fimbriata (12) \\
\hline Aechmea nudicaulis (L.) Griseb. & $11.7 \pm 1.04(55)$ & Ornithophily & P. idaliae (1) \\
\hline Neoregelia cruenta (Graham) L.B.Sm. & $30.3 \pm 3.24(17)$ & Ornithophily & A. fimbriata (5) \\
\hline $\begin{array}{l}\text { Quesnelia quesneliana (Brongn.) } \\
\text { L.B. Sm. }\end{array}$ & $38(1)$ & Ornithophily & $\begin{array}{l}\text { A. fimbriata }(1) \\
\text { P. idaliae (1) }\end{array}$ \\
\hline Tillandsia gardneri Lindl. & $15.7 \pm 1.26(23)$ & Ornithophily & P. idaliae (1) \\
\hline Tillandsia stricta Sol. & $15.6 \pm 1.47(15)$ & Ornithophily & A. fimbriata (1) \\
\hline Vriesea neoglutinosa Mez & $34.0 \pm 2.98(24)$ & Ornithophily & A. fimbriata (13) \\
\hline \multicolumn{4}{|l|}{ Cactaceae } \\
\hline Melocactus violaceus Pfeiff. & $13.0 \pm 1.47(17)$ & Ornithophily & A. fimbriata (5) \\
\hline \multicolumn{4}{|l|}{ Ericaceae } \\
\hline $\begin{array}{c}\text { Gaylussacia brasiliensis (Spr.) Meissn. } \\
\text { Passifloraceae }\end{array}$ & \multicolumn{2}{|c|}{ Passifloraceae } & A. fimbriata (2) \\
\hline *Passiflora alliacea Barb. Rodr. & Open & Melittophily & A. fimbriata (10) \\
\hline
\end{tabular}

to pink colors (Fig. 2). Corolla length of flowers visited by hummingbirds varied from $8.8 \pm 1.2 \mathrm{~mm}$ ( $\mathrm{n}=20$, in Gaylussacia brasiliensis, Ericaceae) to $38 \mathrm{~mm}$ ( $\mathrm{n}=1$, in Quesnelia quesneliana, Bromeliaceae), but non-ornitophilous species with open corollas, were also visited (e.g. Passiflora alliacea) (Table I).

Amazilia fimbriata was the most frequent (abundant) pollinator and recorded every month, while Eupetomena macroura was rare (few records within a day) and observed only in April. The highest frequency of hummingbirds was recorded in August 2006 and the lowest in February 2006 (Table II). Amazilia fimbriata displayed agonistic behavior against individuals of its own species as well as against $E$. macroura.

The resources available to the hummingbirds every month, varied from four (August, November, January and April) to up to seven (February and March) flowering species and from 36 (July) to up to 283 (May) opened flowers (Table II). Flowering was annual for most of the plant species; two species flowered twice a year and three species flowered continuously.

We found variation in the nectar volume produced per flower, ranging from $2.5 \pm 2.2 \mu \mathrm{L}$ (in Tillandsia stricta, Bromeliaceae) to $109.3 \pm$ $68.5 \mu \mathrm{L}$ (in Vriesea neoglutinosa, Bromeliaceae) (Table III). The most diluted nectar among hummingbird-visited flowers was produced by Gaylussacia brasiliensis $(19.9 \pm 4.3 \%)$ and the most concentrated one by Neoregelia cruenta $(31.9 \pm 1.7 \%)$. Mean sugar concentration from nectar produced by ornitophilous hummingbirdvisited species was $24.7 \%$ Brix, while the mean concentration overall was $26.6 \%$ Brix. We found a correlation between nectar volume and corolla length in tubular flowers from the plant assemblage, indicating that longer flowers offered more rewards $(\mathrm{r}=0.89 ; \mathrm{p}<0.01 ; \mathrm{n}=9)$. 
TABLE II

Number of opened flowers per day (phenology) of species visited by hummingbirds from June 2005 to May 2006 inside sampling quadrants, and number of visual records of hummingbird (abundance) in transects from August 2005 to August 2006, in the Restinga de Jurubatiba National Park, Southeastern Brazil. * denotes species recorded with opened flowers outside (but close) to the sampled quadrants and - denotes that the information was not collected.

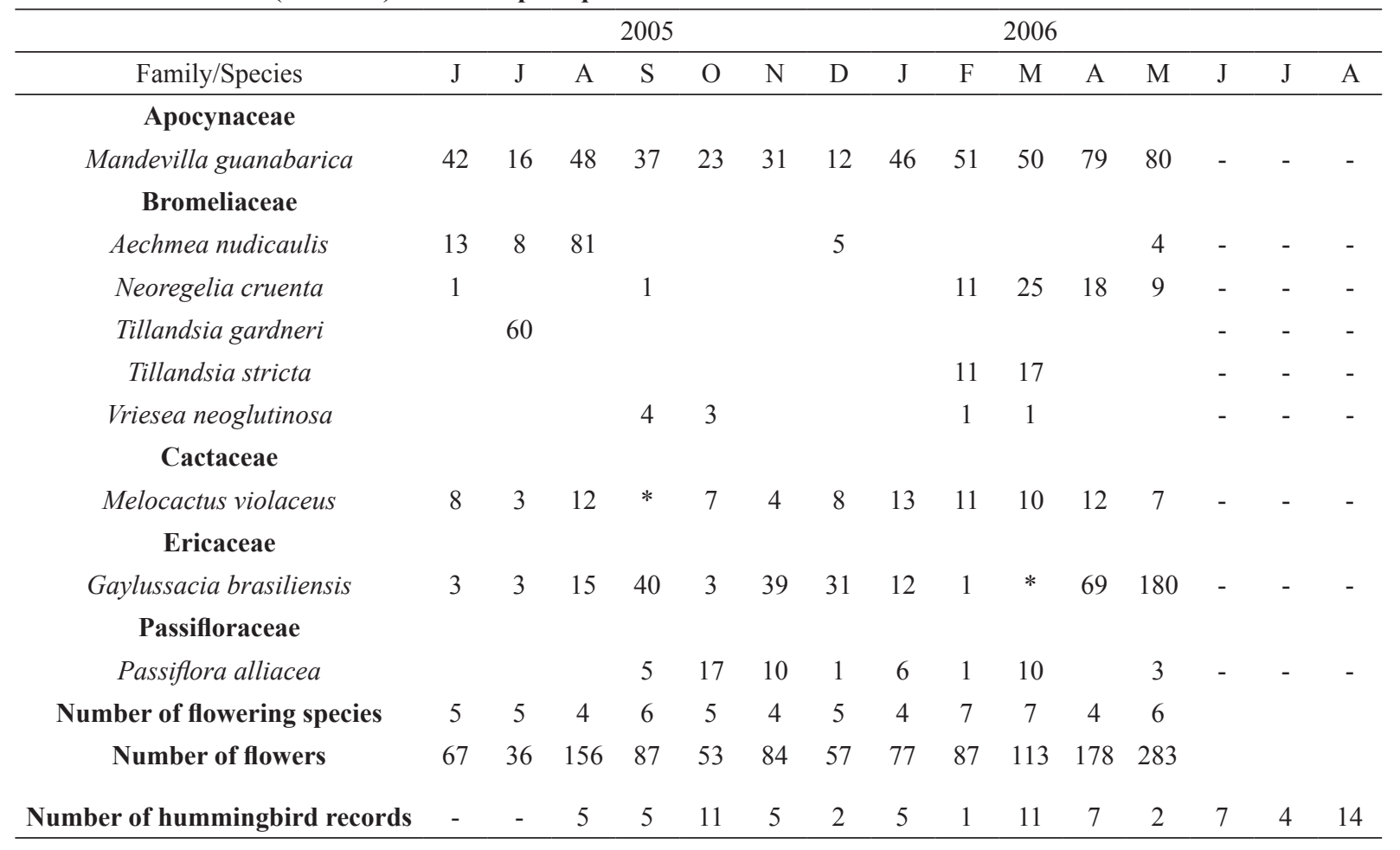

TABLE III

Mean volume $(\mu \mathrm{L})$, sugar concentration (\% Brix) and calories (cal) per flower of plant species visited by hummingbird in Restinga de Jurubatiba National Park, Southeastern Brazil.

\begin{tabular}{cccc}
\hline Family/Species & Volume $\pm \mathrm{sd}(\mathrm{n})$ & Sugar concentration $\pm \mathrm{sd}(\mathrm{n})$ & Calories $\pm \mathrm{sd}(\mathrm{n})$ \\
\hline Apocynaceae & & & \\
\hline Mandevilla guanabarica & $38.1 \pm 14.2(14)$ & $32.5 \pm 1.8(14)$ & $55.3 \pm 19.9(14)$ \\
Bromeliaceae & & & \\
Aechmea nudicaulis & $6.3 \pm 4.9(14)$ & $26.9 \pm 4.7(14)$ & $7.5 \pm 5.4(14)$ \\
Neoregelia cruenta & $69.6 \pm 7.2(7)$ & $31.9 \pm 1.7(7)$ & $100.0 \pm 5.6(7)$ \\
Quesnelia quesneliana & $103.3 \pm 26.8(15)$ & $25.5 \pm 2.7(15)$ & $115.3 \pm 32.6(15)$ \\
Tillandsia gardneri & $7.8 \pm 5.1(23)$ & $20.7 \pm 1.7(23)$ & $7.0 \pm 4.7(23)$ \\
Tillandsia stricta & $2.5 \pm 2.2(19)$ & $22.5 \pm 2.7(13)$ & $122.0 \pm 77.3(21)$ \\
Vriesea neoglutinosa & $109.3 \pm 68.5(21)$ & $24.9 \pm 2.2(21)$ & $9.3 \pm 5.7(19)$ \\
Cactaceae & & & \\
Melocactus violaceus & $7.4 \pm 4.6(20)$ & $25.7 \pm 4.0(19)$ & $4.1 \pm 1.8(11)$ \\
Ericaceae & & $19.9 \pm 4.3(11)$ & $164.2 \pm 32.6(4)$ \\
Gaylussacia brasiliensis & $4.5 \pm 2.5(12)$ & & \\
Passifloraceae & & $36.1 \pm 10.4(4)$ & \\
Passiflora alliacea & $98.8 \pm 35.9(4)$ & &
\end{tabular}


According to our estimations, hummingbirdvisited species together, produced a daily amount of energy varying from 0.87 to $5.97 \mathrm{Kcal}$ per hectare of restinga (open Clusia shrubland). Therefore, an estimated area ranging from one to 6.8 ha would be necessary to support one hummingbird individual with a $6 \mathrm{Kcal} /$ day energetic requirement (Fig. 3).

\section{DISCUSSION}

Amazilia fimbriata was the most important bird pollinating the hummingbird-visited plants at the sampled area in the Jurubatiba restinga. This resident bird was one of the most abundant birds recorded in previous studies using mist nets and transects in the same area (Alves et al. 2004). Studies on other plant-pollinator systems have shown that one or few species are often responsible for most of the pollination inside a guild of flower visitors, acting as core-species (Jordano 1987, Vázquez et al. 2009). Such an extreme case as Jurubatiba restinga, where the pollination by birds is almost exclusively carried out by a single hummingbird, has not been previously reported for tropical ecosystems. To the best of our knowledge, there are only two other cases in which a single species of hummingbird was associated to a hummingbird-pollinated plant assemblage: one in the United States (Robertson 1929) and another in Southern Argentina (Fraga et al. 1997). Both cases are in temperate ecosystems and involve migratory species seasonally using the resources. Therefore, their permanence in these areas is likely constrained by temperature and resource availability during the cold season (Fraga et al. 1997).

Previous studies have shown that flowers with long (and often curved) corolla tubes limit access of hummingbirds with short bills (Arizmendi and Ornelas 1990, Maruyama et al. 2014, VizentinBugoni et al. 2014). All plant species recorded in the studied restinga assemblage showed relatively

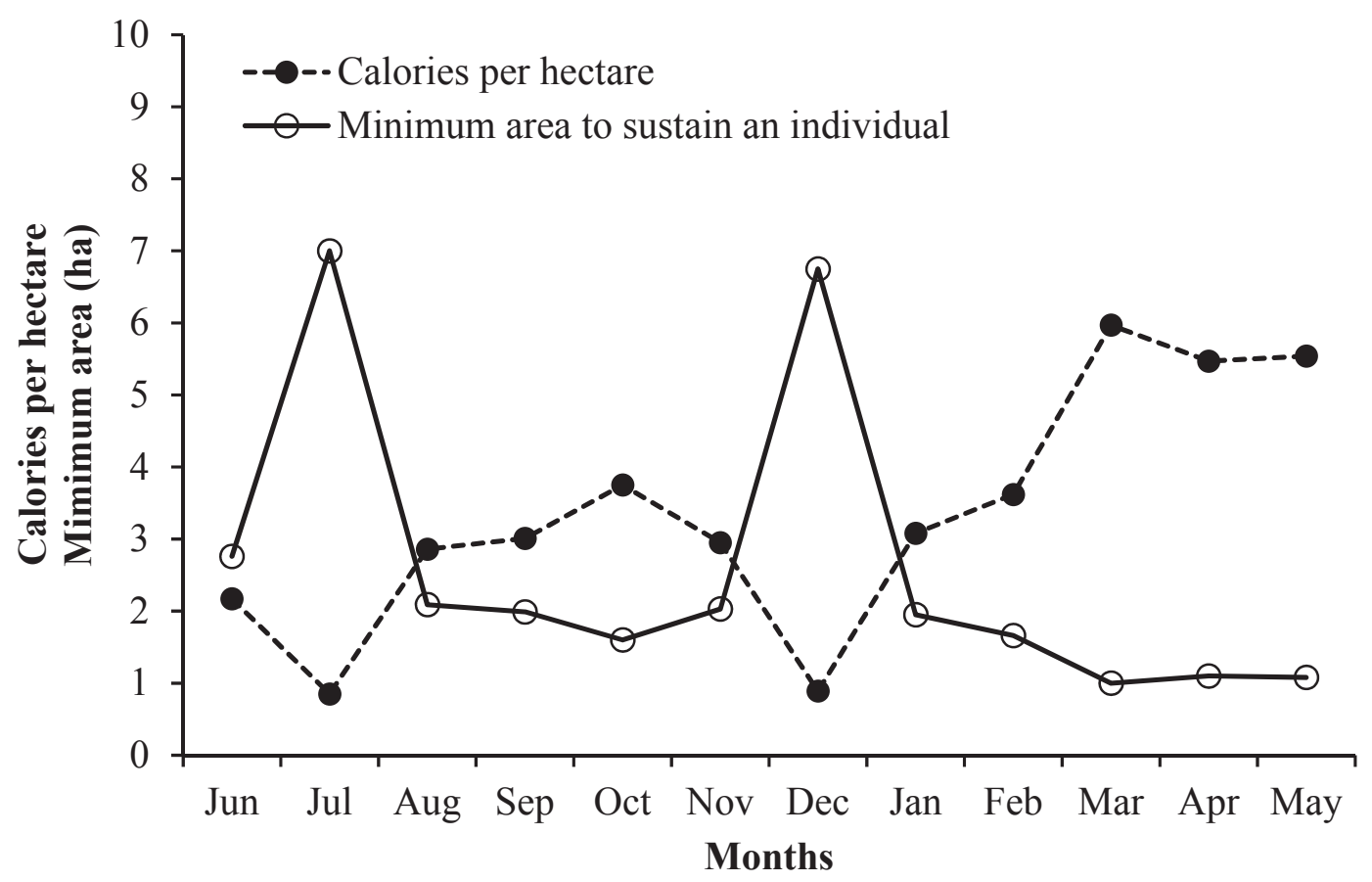

Figure 3 - Estimations of calories produced per hectare by hummingbird-visited plants and the minimum area estimated for a hummingbird to obtain six Kcal from nectar in Restinga de Jurubatiba National Park, Southeastern Brazil, from June 2005 to May 2006. 
short corollas $(<3.5 \mathrm{~cm})$. This pattern implies that flowers can be easily accessed by any hummingbird species and, therefore, morphological mismatch seems not to be an important factor structuring plant-hummingbird interactions at restingas as is the case in the adjacent forested areas (VizentinBugoni et al. 2014) or in the Neotropical savannas (Maruyama et al. 2014).

Functional trait complementarity among hummingbird species is common in natural assemblages (e.g. territorial vs. trapliner) allowing a higher number of coexisting species (Stiles 1975, DesGranges 1979, Feinsinger and Colwell 1978, Arizmendi and Ornelas 1990). We did not find such complementarity, since both A. fimbriata and E. macroura are territorial and morphologically similar species (i.e. similar bill length) (Justino et al. 2012). The absence of species with different ecological roles (sensu Feinsinger and Cowell 1978) is probably due to several non-exclusive factors. The first factor is probably related to the low complexity of the habitat (e.g. absence of stratification), low richness of food-plants and low resource production, limiting the hummingbird richness in similar ways as those reported for bat communities (Fleming 2005). Another reason for low complementarity could be the low variation in corolla length. Long corollas tend to produce highly energetic nectar and to be visited exclusively by long-billed hummingbirds (Feinsinger and Colwell 1978, Arizmendi and Ornelas 1990) thus producing a subset of interactions within the community (i.e. long corolla plants supported by one or few longer billed hummingbird; Maruyama et al. 2014, 2015). Although we found a positive relation between corolla length and nectar volume, corollas were not long enough to constrain the visits of shortbilled hummingbirds (like Amazilia fimbriata and Eupetomena macroura) in the Jurubatiba restinga.

The caloric requirements of hummingbirds may vary depending upon the species (Carpenter 1983, Powers and McKee 1994) but several estimations suggests a variation between six and 10 kcal/day (Lasiewski 1962, Carpenter 1983, Powers and Conley 1994). Considering this energetic requirement and the amount of energy available in the studied area, our estimation suggests that a hummingbird needs to cover an area sometimes larger than six hectares in order to collect enough nectar within this particular phytophysiognomy ("non-flooded open shrubland"). This scenario may have also contributed to the low hummingbird diversity recorded here. This idea is reinforced by Eupetomena macroura (another territorial species that usually holds richer resource patches; Justino et al. 2012), having coexisted with A. fimbriata only during a month of high nectar availability, when resources were likely high enough to be shared. Another factor favoring territorial species might be the scrubland vegetation allowing easier detection and exclusion of intruders. Moreover, antagonistic interactions among hummingbirds elevate their energetic requirements and the presence of other nectar-feeding animals such as bees and butterflies are likely to decrease the amount of nectar available per unit area. Considering these two factors, a hummingbird will likely require a foraging area even larger than that calculated here. To cope with this demand, hummingbirds could enlarge their restinga territories or move between open Clusia shrubland and the other habitats nearby. Amazilia fimbriata was indeed observed and captured in both, forest and restinga areas in Jurubatiba while the other hummingbird recorded was E. macroura, that was around thirty times less abundant and registered only in restinga (Alves et al. 2004). Regardless of the hummingbird response, its higher mobility will potentially favour plant reproduction by increasing the probability of cross pollination and gene flow (Maloof and Inouye 2000, Araujo et al. 2011).

Although varying among species, our results reiterate that nectar of hummingbird-visited flowers contains around $20 \%$ sugar (Arizmendi and Ornelas 1990, Buzato et al. 2000, Navarro 2001, Perret et al. 2001, Cronk and Ojeda 2008, 
Krömer et al. 2008). The interspecific nectar heterogeneity has been interpreted as a prerequisite for the coexistence of hummingbirds with different energetic demands (Snow and Snow 1972, Stiles 1975, Wolf et al. 1976) however; such coexistence was not recorded in the Jurubatiba restinga. This suggests that differences in nectar concentration are not sufficient to determine the coexistence of hummingbird species (Brown and Bowers 1985, Kodric-Brown et al. 1984). It was already shown that the frequency of plant-hummingbird interactions are more related to other mechanisms (e.g. constraints imposed by flower morphology and spatio-temporal distribution of plants and pollinators) than to differences in nectar rewards (Maruyama et al. 2014). However, the nectar produced by all hummingbird-visited plants is important to attract and maintain the pollinators in the area, which in turn could facilitate the reproduction of the hummingbird-pollinated species (Maruyama et al. 2013).

The pollination by hummingbirds at the "open Clusia shrublands" vegetation in Jurubatiba was carried out almost exclusively by Amazilia fimbriata. This implies that several plants share the same pollinator. From the plant perspective, sharing pollinators could be disadvantageous since mixed pollen deposition may lead to waste of gametes and the risk of hybridization (Campbell and Motten 1985, Moragues and Traveset 2005). Previous studies on hummingbird communities where plants shared the same pollinator species, have found phenological segregation, which have been interpreted as co-adaptation of plants to reduce the overlap in the use of pollen vectors (Stiles 1975, 1977, Buzato et al. 2000). Many species overlap their flowering periods at Jurubatiba restinga, although the flower peaks of each species were not coincident, reducing the possible problems of pollen mixture.

Additionally, as usually described for other Neotropical communities (Vasconcelos and
Lombardi 2001, Arizmendi and Ornelas 1990, Buzato et al. 2000, Araujo et al. 2011, but see Araújo and Sazima 2003, Maruyama et al. 2013, 2015), we recorded ornithophilous traits (e.g. absence of scent in red tubular flowers open during the day) in most of the hummingbird-visited species at Jurubatiba restinga. Despite the prevalence of ornithophilous traits, bees and butterflies were also recorded in some hummingbird-visited species. Therefore, in future studies we claim to take into account the role of insects on the reproduction of restingas "ornithophilous" plants. The importance of insects could be especially high in a scenario of overlap both in flowering periods and pollen placement on one hummingbird species, as we reported for Jurubatiba restinga. This is reinforced by the pollination of Aechmea nudicaulis which although presents ornithophilous flowers, is also pollinated by bees in other restinga areas (Schmid et al. 2011).

\section{CONCLUSIONS}

Our study reports an unusual situation in which a tropical plant-hummingbird system is visited by a single hummingbird species. Additionally, our results indicate the need of large areas of restinga to support populations of hummingbirds that, in turn, are necessary to maintain the restinga vegetation (including many of the nurse plants). Lastly, we highlight that the hummingbirds-plants interactions in restinga are interesting for future studies aiming to understand the effects of nectar dynamics on hummingbird life area and its implications on plant pollination as well as to disentangle the different roles of flower visitors at community level.

\section{ACKNOWLEDGMENTS}

We thank the staff at the Laboratório de Ecologia de Aves/Universidade do Estado do Rio de Janeiro (UERJ) and at the Núcleo em Ecologia e Desenvolvimento Sócio Ambiental em Macáe (NUPEM); the Brazilian Agency for Research 
- Conselho Nacional de Desenvolvimento Científico e Tecnológico (CNPq) for scholarship to L.C.N.F., scholarship and research grant to M.A.S.A; (proc. 308792/2009-2); Fundação de Amparo à Pesquisa do Estado do Rio de Janeiro (FAPERJ) - State Agency for Research (proc. E-26/102837/2012) for the research grant to M.A.S.A. The work was conducted under license \#163/2005 (IBAMA); JVB and ARR were supported by Coordenação de Aperfeiçoamento de Pessoal de Nível Superior (CAPES) through a PDSE scholarship (proc.: 99999.008012/2014-08) and a Post-Doc Scholarship (Proc. 1141XPOS023), respectively. This work is a sub-project of Grupo de Vertebrados/PELD - site 5/CNPq, with the birds group coordenated by M.A.S.A. We are grateful to J.E. Meireles who helped in field work; Andrew MacDonald and Pietro K. Maruyama and four anonymous reviewers for the suggestions on the first drafts; Kathryn Harrold and Hilary Erenler who reviewed the English; Claudio Nicoletti de Fraga and Dinkum gently donated plant pictures and Marcelo Freire Moro helped with the map.

\section{RESUMO}

Beija-flores são o grupo mais especializado e importante de aves polinizadoras na região neotropical e suas interações com plantas são componentes chave de muitas comunidades. No presente estudo, identificamos o conjunto de plantas visitadas por beija-flores e investigamos a variação temporal nos recursos florais em uma área de restinga (vegetação costeira arenosa associada à Mata Atlântica), no sudeste do Brasil. Registramos as características florais e do néctar, a fenologia de floração e as interações entre plantas e beija-flores e estimamos a quantidade de calorias produzida por hectare entre de 2005 a agosto de 2006. Dez espécies de plantas foram visitadas por dois beijaflores (Amazilia fimbriata e Eupetomena macroura). A disponibilidade do recurso foi altamente variável entre as espécies de planta e ao longo do tempo. O volume e a concentração de néctar por flor foram similares aos relatados para outras assembleias de plantas visitadas por beija-flores na região Neotropical. A disponibilidade de recurso de néctar estimada entre meses variou entre 0,85 e 5,97 Kcal por hectare/dia, demandando uma área entre um e 6,8 ha para manter um único indivíduo de beija-flor. Nosso estudo relata uma situação tropical incomum onde quase todas as interações entre beijaflores e plantas foram realizadas por uma única espécie de beija-flor, A. fimbriata. Dessa forma, a variação na disponibilidade de néctar provavelmente influencia os deslocamentos do beija-flor, sua área de forrageamento e consequentemente a polinização das plantas.

Palavras-chave: Amazilia fimbriata, Mata Atlântica, recursos florais, ornitofilia, polinização, restinga.

\section{REFERENCES}

ABRAHAMCZYC S AND KESSLER M. 2015. Morphological and behavioural adaptations to feed on nectar - how feeding ecology determines the diversity and composition of hummingbird assemblages. J Ornithol 156: 333-347.

Alves MAS, Storni A, Almeida EM, Gomes VSM, OLIVEIRA CHP, MARQUES RV AND VECCHI MB. 2004. A comunidade de aves na Restinga de Jurubatiba. In: Rocha CFD, Esteves FA and Scarano FR (Eds), Pesquisas de Longa Duração na Restinga de Jurubatiba: Ecologia, História Natural e Conservação. São Carlos: RiMa, p. 199214.

ARAÚJO AC AND SAZIMA M. 2003. The assemblage of flowers visited by hummingbirds in the capões of southern Pantanal, Mato Grosso do Sul, Brazil. Flora 198: 1-9.

ARAUJO DSD, SCARANO FR, SÁ CFC, KURTZ BC, ZALUAR HLT, MONTEZUMA RCM AND OlIVEIRA RC. 1998. Comunidades vegetais do Parque Nacional da Restinga de Jurubatiba. In: Esteves FA (Ed), Ecologia das lagoas costeiras do Parque Nacional da Restinga de Jurubatiba e do Município de Macaé (RJ). Universidade Federal do Rio de Janeiro, Rio de Janeiro, p. 39-62.

ARAUJO FP, BARBOSA AAA AND OLIVEIRA PE. 2011. Floral resources and hummingbirds on an island of flooded forest in Central Brazil. Flora 206: 827-835.

ARIZMENDI MC AND ORNELAS JF. 1990. Hummingbirds and their floral resources in a tropical dry forest in México. Biotropica 22: 172-180.

BAWA KS. 1990. Plant-pollinator interactions in Tropical Rain Forests. Am J Bot 72: 346-456.

BROWN JH AND BOWERS MA. 1985. Community organization in hummingbirds: relationships between morphology and ecology. Auk 102: 251-269.

BuZATO S, SAZIMA M AND SAZIMA I. 2000. Hummingbirdpollinated floras in three Atlantic Forest sites. Biotropica 32: $824-841$. 
CAMPBELL DR AND MOTTEN AF. 1985. The mechanism of competition for pollination between two forest herbs. Ecology 66: 554-563.

CARPENTER FL. 1983. Pollination energetics in avian communities: simple concepts and complex realities. In: Jones EC and Little JR (Eds), Handbook of Experimental Pollination Biology. Van Wostrand. Scientific and Academic Editions, p. 215-234.

COTTON PA. 2000. Seasonal resource tracking by Amazonian hummingbirds. Ibis 149(1): 135-142.

CRONK Q AND OJEDA I. 2008. Bird-pollinated flowers in an evolutionary and molecular context. J Exp Bot 59: 715527.

DAFNI A. 1992. Pollination ecology: a practical approach. IRL Press. Oxford, $250 \mathrm{p}$.

DESGRANGES JL. 1979. Organization of a tropical nectar feeding bird guild in a variable environment. Living Bird 17: 199-236.

FEINSINGER P AND COLWELL R. 1978. Community organization among neotropical nectar-feeding birds. Am Zool 18: 779-795.

FLEMING TH. 2005. The relationship between species richness of vertebrate mutualists and their food plants in tropical and subtropical communities differs among hemispheres. Oikos 111: 556-562.

FRAGA RM, RUFFINI AE AND GRIGERA D. 1997. Interacciones entre el picaflor rubi Sephanoides sephaniodes y las plantas del bosque Subantártico en el Parque Nacional Nahuel Huapi, Argentina. Hornero 14: 224-234.

GALETTO L AND BERNARDELlo G. 2003. Sugar nectar composition in angiosperms from Chaco and Patagonia (Argentina): animal visitor's matter? Plant Syst Evol 238: 69-86.

HENRIQUes RPB, ARAuJo DSD AND REIS JD. 1986. Descrição e classificação dos tipos de vegetação da Restinga de Carapebus, Rio de Janeiro. Rev Bras Bot 9: 173-189.

INOUYE DW, FAVRE ND, LANUN JA, LEVINE DM, MEYERS JB, ROBERTS MS, TSAO FC AND WANG YY. 1980. The effect of non-sugar nectar constituents on estimates of nectar energy content. Ecology 61: 992-995.

JORDANO P. 1987. Patterns of mutualistic interactions in pollination and seed dispersal: connectance, dependence asymmetries, and coevolution. Am Nat 129: 657-677.

JUSTINO DG, MARUYAMA PK AND OLIVEIRA PE. 2012. Floral resource availability and hummingbird territorial behaviour on a Neotropical savanna shrub. J Ornithol 153 (1): 189-197.

KODRIC-BROWN A, BROWN JH, BYERS GS AND GORI DF. 1984. Organization of a tropical community of hummingbirds and flowers. Ecology 65: 1358-1368.

KRÖMER T, KESSLER M, LOHAUS G AND SCHIMIDT-LEBUHN AN. 2008. Nectar sugar composition and concentration in relation to pollination syndromes in Bromeliaceae. Plant Biology 10: 502-511.
LASIEWSKI RC. 1962. The energetics of migrating hummingbirds. Condor 64: 324.

Magnago LFS, Martins SV AND PEREIRA OJ. 2011. Heterogeneidade florística das fitocenoses de restingas nos estados do Rio de Janeiro e Espírito Santo, Brasil. Rev Árvore 35(2): 245-254.

MALOOF JE AND INOUYE DW. 2000. Are nectar robbers cheaters or mutualists? Ecology 10:2651-2661.

MARUYAMA PK, OLIVEIRA GM, FERREIRA C, DALSGAARD B AND OLIVEIRA PE. 2013. Pollination syndromes ignored: importance of non-ornithophilous flowers to Neotropical savanna hummingbirds. Naturwissenschaften 100: 1061-1068.

MARUYAMA PK, VIZENTIN-BUGONI J, DALSGAARD B, SAZIMA I AND SAZIMA M. 2015. Nectar robbery by a hermit hummingbird: association to floral phenotype and its influence on flowers and network structure. Oecologia 178: 783-793.

MARUYAMA PK, VIZENTIN-BUGONi J, OLIVEIRA GM, OLIVEIRA PE AND DALSGAARD B. 2014. Morphological and spatio-temporal mismatches shape a neotropical savanna plant-hummingbird network. Biotropica 46: 740747.

MCDADE LA AND WEEKS JA. 2004. Nectar in Hummingbirdpollinated Neotropical Plants I: Patterns of Production and Variability in 12 Species. Biotropica 36: 196-215.

MENDONÇA LB AND ANJOS L. 2003. Bird-flower interactions in Brazil: a review. Ararajuba 11: 195-205.

MORAGUES E AND TRAVESET A. 2005. Effect of Carpobrotus spp. on the pollination success of native plant species of the Balearic Islands. Biol Conserv 122: 611-619.

NAVARRO L. 2001. Reproductive biology and effect of nectar robbing on fruit production in Macleania bullata (Ericaceae). Plant Ecol 152: 59-65.

OLIVEIRA PE AND GIBBS PE. 2000. Reproductive biology of woody plants in a cerrado community of the central Brazil. Flora 195: 311-329.

Perret M, Chautems A, Spichiger R, Peixoto M AND SAVOLAINEN V. 2001. Nectar sugar composition in relation to pollination syndromes in Sinningieae (Gesneriaceae). Ann Bot-London 87: 267-273.

POWERS DR AND CONLEY TM. 1994. Field metabolic rate and food consumption of two sympatric hummingbird species in Southeastern Arizona. Condor 96(1): 141-150.

POWERS DR AND MCKEE T. 1994. The effect of food availability on time and energy expenditures of territorial and non-territorial hummingbirds. The Condor 96: 10641075.

PYKE GH. 1991. What does it cost a plant to produce floral nectar? Nature 350: 58-59.

ROBERTSON C. 1929. Flowers and insects: lists of visitors to four hundred and fifty-three flowers. Carlinville, IL: C. Robertson, $221 \mathrm{p}$. 
SAMPAIO MC, PICÓ FX AND SCARANO FR. 2005. Ramet demography of a nurse bromeliad in brazilian restingas. Am J Bot 92: 674-681.

SCARANO FR. 2002. Structure, function and floristic relationships of plants communities in stressful habitats marginal to Brazilian Atlantic Rainforest. Ann Bot-London 90: 517-524.

SCARANO FR, DUARTE HM, RIBEIRO KT, RODRIGUES PJFP AND BARCELlOS EMB. 2001. Four sites contrasting environmental stress in southeastern Brazil: relations of species, life form diversity, and geographic distribution to ecophysiological parameters. Bot J Linn Soc 136: 345 364.

SCHMID S, SCHMID VS, ZILIKENS A, HARTER-MARQUES B AND STEINER J. 2011. Bimodal pollination system of the bromeliad Aechmea nudicaulis involving hummingbirds and bees. Plant Biology 13: 41-50.

SNOW BK AND SNOW DW. 1972. Feeding niches of hummingbirds in a Trinidad valley. J Anim Ecol 41: 471485.

SOUZA CRG, HIRUMA ST, SALLUM AEM, RIBEIRO RR AND SOBRINHO JMA. 2008. Restinga: Conceitos e Empregos do termo no Brasil e implicações na legislação ambiental. São Paulo - Instituto Geológico, 104 p.

STILES FG. 1975. Ecology, flowering phenology, and hummingbird pollination of some Costa Rican Heliconia species. Ecology 56(2): 285-301.
STILES FG. 1977. Coadapted pollinators: The flowering seasons of hummingbird-pollinated plants in a tropical forest. Science 198: 1177-1178.

STILES FG. 1978. Temporal organization of flowering among the hummingbird food plants of a tropical wet forest. Biotropica 10: 194-210.

STILES FG. 1981. Geographical aspects of bird-flower coevolution, with particular reference to Central America. Ann Mo Bot Gard 68: 323-351.

STILES FG. 1985. Seasonal patterns and coevolution in the hummingbird-flower community of a Costa Rican subtropical forest. Ornithol Monogr 36: 757-787.

VASCONCELOS MF AND LOMBARDI JA. 2001. Hummigbirds and their flowers in the campos rupestres of Southern Espinhaço Range, Brazil. Melopsittacus 4: 1-30.

VÁZQueZ DP, BLÜTHGEN N, CAGNOLO L AND CHACOFF NP. 2009. Uniting pattern and process in plant-animal mutualistic networks: a review. Ann Bot-London 103: 1445-1457.

Vizentin-Bugoni J, Maruyama PK And SAZIMA M. 2014. Processes entangling interactions in communities: forbidden links are more important than abundance in a hummingbird-plant network. Proc R Soc B 281: 23972407.

WOLF LL, STILES FG AND HAINSWORTH FR. 1976. Ecological organization of a tropical, high land hummingbird community. J Anim Ecol 32: 349-379. 
